\title{
Recent Advances in the Measurement of Arsenic, Cadmium, and Mercury in Rice and Other Foods
}

\author{
Brian P. Jackson • Tracy Punshon
}

Published online: 16 January 2015

(C) Springer International Publishing AG 2015

\begin{abstract}
Trace element analysis of foods is of increasing importance because of raised consumer awareness and the need to evaluate and establish regulatory guidelines for toxic trace metals and metalloids. This paper reviews recent advances in the analysis of trace elements in food, including challenges, state-of-the-art methods, and use of spatially resolved techniques for localizing the distribution of arsenic and mercury within rice grains. Total elemental analysis of foods is relatively well-established, but the push for ever lower detection limits requires that methods be robust from potential matrix interferences, which can be particularly severe for food. Inductively coupled plasma mass spectrometry (ICP-MS) is the method of choice, allowing for multi-element and highly sensitive analyses. For arsenic, speciation analysis is necessary because the inorganic forms are more likely to be subject to regulatory limits. Chromatographic techniques coupled to ICP-MS are most often used for arsenic speciation, and a range of methods now exist for a variety of different arsenic species in different food matrices. Speciation and spatial analysis of foods, especially rice, can also be achieved with synchrotron techniques. Sensitive analytical techniques and methodological advances provide robust methods for the assessment of several metals in animal- and plant-based foods, particularly for arsenic, cadmium, and mercury in rice and arsenic speciation in foodstuffs.
\end{abstract}

This article is part of the Topical Collection on Food, Health, and the Environment

B. P. Jackson $(\bowtie)$

Department of Earth Sciences, Dartmouth College,

Hanover, NH, USA

e-mail: Brian.P.Jackson@dartmouth.edu

T. Punshon

Department of Biological Sciences, Dartmouth College,

Hanover, NH, USA
Keywords Arsenic $\cdot$ Cadmium $\cdot$ Mercury $\cdot$ Food · Speciation $\cdot$ Analytical methods

\section{Introduction}

Arsenic is a naturally occurring element present in water, soils, and rock; it is also a toxic element, and both inorganic and organic arsenic compounds have been used widely in agriculture and livestock throughout the 20th century as insecticides, pesticides, and antibiotics. Consequently, it is not surprising that arsenic is found at detectable levels in many food crops. Additionally, marine fish, marine algae (seaweed), and rice all concentrate arsenic from the environment. Methylmercury bioaccumulates in the food chain and is found at elevated levels in many higher trophic-level aquatic organisms. The US Food and Drug Administration (FDA) has a maximum concentration limit of $1 \mathrm{mg} / \mathrm{kg}$ for methylmercury in fish [1]. Mercury uptake in rice grown on contaminated soils is also of recent concern. Cadmium is another toxic nonessential element that is present in food; for non-smokers, food is the major source of exposure. The European Food Safety Authority (EFSA) has set maximum limits for cadmium in a variety of foodstuffs and, in 2013, released a draft that amended these regulations to include cocoa and chocolate products [2]. Clearly there is a continued need for robust analytical methods to determine the concentration and speciation of these toxic elements in food.

Total elemental analysis in food is, in principle, no different than elemental analysis in any other biological matrix. The solid sample first requires solubilization, most usually accomplished by acid digestion, followed by analysis of the resulting digestate by a suitable analytical technique, for instance inductively coupled plasma mass spectrometry (ICP-MS). A holistic overview for single laboratory-validated analysis of metals 
in food has recently been outlined [3]. The general approach of acid digestion followed by ICP-MS analysis is probably the most routine method currently used for multi-element analysis of food products. A standardized method utilizing highpressure digestion has been reported for arsenic, cadmium, mercury, and lead in foods [4].

Food is particularly challenging, because the matrix can be high in low-molecular-weight organics, which, if not completely decomposed during acid digestion, can cause severe matrix effects during analysis, as noted in the ICP-MS analysis of wines [5] and fish [6]. The presence of these lowmolecular-weight carbon compounds has a pronounced effect on the analysis of high ionization potential elements, arsenic, selenium, and mercury, by ICP-MS that, if uncorrected, can lead to significant over-estimation of the concentration of these elements $[7,8]$. Trace element concentrations in food are usually quite low, for instance and as will be discussed later, a potential guideline limit for arsenic in rice that has been discussed is $0.2 \mu \mathrm{g} / \mathrm{g}$ [9]; assuming the digestion procedure introduces a dilution of 100-fold, then the actual concentration in the solution to be analyzed is $2 \mu \mathrm{g} / \mathrm{L}$. This effectively means that only very sensitive analytical instrumentation can be used for trace element analysis in food and that methods must be robust, precise, and accurate as even a small positive bias could cause a sample to appear above a maximum limit.

For arsenic and mercury analysis, a measure of the total amount of these elements is not sufficient, because both occur in different ionic or molecular forms (species) in food and these different species have different toxicities [10]. Methodology for speciation analysis is relatively well established for both of these elements. Arsenic speciation is most often accomplished by liquid chromatography (usually anion exchange chromatography) coupled to an elementspecific detector. Mercury speciation most often involves gas chromatography and element-specific detection. For arsenic, it is usual to measure the presence of at least five species, arsenite, arsenate, arsenobetaine, monomethylarsonate (MMA), and dimethylarsinate (DMA), although in some foodstuffs that contain seafood or seaweed there may be additional organoarsenic species present such as arsenosugars [11]. In any case, the need for analytical methods with low detection limits becomes even more pressing when quantifying the individual species present.

In this review, we summarize the recent advances for the measurement of total arsenic and arsenic species in food, and particularly in rice and rice products. We also review the occurrence and concentration of cadmium and mercury in rice. We focus mostly on methods utilizing ICP-MS as the detector, increasingly recognized as the analytical technique of choice for low-level multi-element analysis. However, optical emission spectroscopy (ICP-OES), atomic fluorescence spectroscopy (AFS), graphite furnace atomic absorption (and the coupling of cold vapor or hydride generation with any of these techniques) all remain viable analytical techniques and are also discussed where appropriate. We also briefly review synchrotron techniques, which offer unique insights into in situ elemental analysis of spatial location and oxidation state mapping of foods such as rice grain.

\section{Determination of Total Trace Element Concentrations in Food}

Collision/Reaction Cell Inductively Coupled Plasma Mass Spectrometry (ICP-MS) Approaches to Alleviate Interferences in Food Analysis

ICP-MS offers distinct advantages for trace element analysis, including the multi-element capabilities and the high sensitivity. However, matrix effects on precision and accuracy can be severe. Polyatomic interferences, where two or more atoms combine in the plasma with the same mass as the target analyte, have largely been overcome by the advent of collision cell [12] and reaction cell technology [13]. Reaction cell approaches use a specific cell gas either to remove an isobaric interferent or to shift the detection mass for the analyte [13]. Ammonia has been used to suppress argon dimers and bromine hydrides and was shown to be effective for accurate determination of selenium in the US National Institute of Standards and Technology (NIST) tomato leaves 1537a where selenium is at $0.12 \mu \mathrm{g} / \mathrm{g}$ and bromine at $11 \mu \mathrm{g} / \mathrm{g}$ [14]. Methane is also efficient for selenium analysis in selenium-enriched rice [15]. Argon chloride interference on arsenic at $\mathrm{m} / \mathrm{z} 75$ was suppressed by using methane or by mass shifting detection to $\mathrm{m} / \mathrm{z} 91$ by reaction with oxygen; detection of $\mathrm{AsO}$ at $\mathrm{m} / \mathrm{z} 91$ yielded the lowest detection limits, and the approach yielded accurate results for seaweed and yellow croaker reference materials, both of which are high in chlorine [16]. Such reaction cell methods are also particularly suited to avoiding doubly charged interferences of rare earth elements (REEs) on arsenic analysis by mass shifting arsenic to $\mathrm{m} / \mathrm{z} 91$ [17].

ICP-MS analysis of food digests must also compensate for matrix effects on analyte sensitivity. For instance, sensitivity for arsenic and selenium increases in the presence of organic solvents, a phenomenon already reported in 1994 [18]. In fact, the addition of an organic modifier, usually methanol, to chromatographic mobile phases to enhance sensitivity for arsenic speciation is now commonplace in most approaches. The effect of residual organics in solution on the enhanced sensitivity of certain elements was recently reviewed [8]. In summary, phosphorus, arsenic, selenium, antimony, tellurium, iodine, gold, and mercury signals were always higher in carbon-containing solutions. The impact of residual organics raises a challenge for food analysis because the residual carbon background (and hence degree of signal enhancement) can differ between samples. Perhaps the most robust approach 
in this instance is calibration by the method of standard additions, because the calibration standards experience the same degree of signal enhancement as the unspiked sample. This is a viable alternative when all samples have a similar matrix and can all be run against one standard additions curve, but becomes very time consuming when it must be performed for every sample due to variable sample matrix. An alternative approach is to add a swamping organic solvent to the sample. For example, in the analysis of infant formula, it is now common to add a fixed volume of methanol to all digested samples and standards to normalize organic matrix within the sample batch and enhance selenium sensitivity [19-21], and this approach should also be applicable to arsenic, mercury, and cadmium. A similar effect can be achieved by adding butanol [22] or isopropanol on-line via the internal standard mixture, which is then introduced into the sample line via a mixing block. Appropriate use of internal standards, i.e. tellurium for arsenic and selenium, as suggested by results of Grindlay et al. [8], can also correct these matrix-based sensitivity increases to some extent.

\section{Arsenic, Cadmium, and Mercury Concentrations in Food}

\section{Arsenic}

Seafood The main source of total arsenic to diet is seafood, where total arsenic concentrations can reach $>10 \mathrm{mg} / \mathrm{kg}$. However, in seafood, arsenic is predominantly present as arsenobetaine [23], an organic arsenic compound that is nontoxic and readily excreted in urine. Recent studies have highlighted fat-soluble arsenolipids that have been reported at $\mathrm{mg} / \mathrm{kg}$ levels in fish oils and in some fish muscle. In vitro cellular toxicity studies on bladder and liver cells suggest that these arsenolipids have equivalent toxicity to inorganic arsenic exposure [24•].

Poultry Arsenic exposure to the US population through poultry consumption is of concern because of the long-standing and widespread use of organoarsenic feed additives in poultry, turkey, and swine production. The most widely used arsenic feed additive was roxarsone (3-nitro 4-hydroxyphenylarsonic acid), which, counter to industry claims, has been shown to be microbially degraded, with one of the products being inorganic arsenic [25-28]. A 2011 FDA study found that significantly higher concentrations of inorganic arsenic were detectable in poultry meat from chickens fed with the roxarsone-added feed compared with a control group [29]. As a consequence, roxarsone and two other structurally similar arseniccontaining antibiotics, carbasone and p-arsanilic acid, have been withdrawn from use and are no longer fed to animals in the USA, although roxarsone is still used in China. Nitrasone, 4-nitrophenylarsonic acid, is still used in the USA for the control of blackhead disease in turkey production.
Rice Concentration ranges of arsenic in rice and rice products have been extensively tested [30-38]. Total arsenic concentrations in rice vary widely as a function of rice cultivar, geography, environment, and growing conditions [39••]. Arsenic can vary spatially within the grain, with inorganic arsenic being higher in the bran layers [40] (see below). In 2014, the World Health Organization (WHO)/Food and Agriculture Organization of the United Nations (FAO), through the CODEX Alimentarius has proposed a guideline level for inorganic arsenic in polished and husked rice of $0.2 \mathrm{mg} / \mathrm{kg}$ [9], but consensus was not reached for inorganic levels in brown rice. Another particular area of study has been the levels of total and inorganic arsenic in rice products specifically marketed for infants and children [41-45] whose low body weight compared with adults puts them disproportionally at risk from exposure to contaminants. Overall, future guideline levels for rice need to be evidence-based while considering feasibility and technical challenges.

Seaweed Marine algae (seaweed) contains $\mathrm{mg} / \mathrm{kg}$ levels of arsenic, present mostly as arsenosugars, which are thought to be of potential toxicity due to metabolite formation and tissue accumulation [46]. Seaweed-based snacks and foods are common in Korea and Japan and are of increasing popularity in the USA. Seaweed is used as a feed additive in dairy farming in the USA and as a soil fertilizer [47]. Seaweeds usually contain low concentration of inorganic arsenic, although one species, hijiki, had concentrations of approximately $100 \mathrm{mg} / \mathrm{kg}$ of total arsenic, with $71 \%$ being inorganic [48]. Clearly this is an unsafe level of inorganic arsenic, and food safety authorities in many countries advise against consumption of this particular species.

\section{Cadmium in Rice}

Cadmium accumulates in rice when it is grown aerobically, whereas arsenic concentrations are highest when rice is grown under flooded conditions [49, 50]. A summary of ICP-MS analysis of rice grain cadmium from market basket studies in 12 countries showed mean concentration ranges from 0.006 to $0.099 \mathrm{mg} / \mathrm{kg}$. For populations with high rice cadmium and high rice consumption, such as Bangladesh or Japan, cadmiumcontaminated rice is a major health concern [51, 52]. ICP-MS [50-52], graphite furnace atomic absorption spectrometry (AAS) [53] and also AAS with solid-phase extraction [54] have all been used as sensitive detectors for cadmium analysis.

\section{Mercury in Rice}

Rice has also been shown to bioaccumulate methylmercury [55] in the grain. Published studies have largely focused on Chinese rice grown in mercury-contaminated soils [56-58]. Growing rice aerobically reduced methylmercury content by 
reducing the activity of mercury methylating bacteria in the soil [59]. Concentrations of total mercury and methylmercury are on the order of 0.1 and $0.01 \mathrm{mg} / \mathrm{kg}$, respectively [60,61]. For individuals eating primarily rice-based diets, then these levels are of concern, especially as methylmercury, the most toxic mercury species, concentrates in the rice grain [62]. Methods for total mercury analysis of rice have been compared, and acid digestion ICP-MS or cold vapor AAS (CVAAS) have been found to be comparable to solid sampling mercury analysis, and satisfactory accuracy for rice reference material NIST 1558a was obtained [63].

\section{Arsenic Speciation in Rice}

The main arsenic species in rice are inorganic arsenic and DMA with trace amounts of MMA also occasionally detected. The proportions of DMA and inorganic arsenic vary with rice cultivar and environmental conditions [39••], with the former appearing to be the major driver. Rice grown from Asian countries has a linear relationship between total arsenic and inorganic arsenic, with an average $78 \%$ of total being inorganic arsenic, whereas US rice exhibits a hyperbolic relationship between inorganic arsenic and total arsenic, with inorganic arsenic having maximum values of $0.15 \mathrm{mg} / \mathrm{kg}$ and total arsenic having maximum values $>0.4 \mathrm{mg} / \mathrm{kg}$ [64]. It has been suggested that the widespread use of MMA and DMA as pesticides and defoliants in cotton production in South Central USA may be the cause of high levels of DMA in US rice now cultivated in that area; however, no data exist to substantiate this assertion, and DMA and MMA are thought to have relatively short half-lives in soil. Rice does not methylate arsenic [65], but does preferentially translocate DMA to rice grain. Elevated soil arsenic and soil conditions that favor net microbial methylation of inorganic arsenic appear to control the ultimate DMA concentration in the grain [64].

Speciation analysis generally employs some form of chromatography to separate the arsenic compounds coupled to element-specific detection. For fish, rice, and seaweed, where the expected arsenic species are mostly anionic, anion exchange chromatography using phosphate- or carbonatebased eluents are most frequently used [11]. The elementspecific detector is often ICP-MS but can also be AFS when coupled to HG [66]. Accurate, precise, and meaningful speciation data depend on quantitative extraction efficiency from the solid, species fidelity during extraction (i.e. the extraction method does not change the distribution of species in the sample), and a sensitive and accurate analytical technique. One of the first reports on arsenic speciation in rice used $2 \mathrm{M}$ trifluoroacetic (TFA) acid extraction [38]; the method gave good arsenic species recoveries of $64-99 \%$ of total arsenic. The TFA extraction method was used by Williams et al. [36] in their paper on levels and speciation of arsenic across rice varieties of different international origin. A simpler extraction method using $1-2 \% \mathrm{HNO}_{3}$ at temperatures of approximately $95{ }^{\circ} \mathrm{C}$ was demonstrated to be effective for extraction and speciation of arsenic from marine and animal tissue [67], and this general approach has been adopted by many groups for arsenic extraction from foodstuffs [42, 43, 68-70]. Because extraction can cause a species interchange between $\operatorname{arsenic}(\mathrm{III})$ and $\operatorname{arsenic}(\mathrm{V})$, and a combined measure of inorganic arsenic is often employed for reporting purposes, it is common to also add $\mathrm{H}_{2} \mathrm{O}_{2}$ to the $\mathrm{HNO}_{3}$ extraction to oxidize all inorganic arsenic to arsenic $(\mathrm{V})$ [44]. Other extraction methods, such as enzymatic extraction with amylase, have also been shown to yield quantitative recovery of arsenic species from rice [71].

In 2011, an international laboratory proficiency test (IMEP 107), where identical unknown test samples are sent to individual laboratories with the goal of assessing the robustness of methodologies, was organized by the EU Reference Laboratory for Heavy Metals in Feed and Food for the determination of inorganic arsenic in rice; seven expert laboratories and 98 participant laboratories were included [72]. The results of this test showed that the determination of total and inorganic arsenic from rice was not a function of the extraction or analysis method. Only 32 of the 98 participating laboratories performed speciation analysis and reported a value for inorganic arsenic; $75 \%$ of the reported results had satisfactory zscores. The authors of the study suggested that concerns that determination of inorganic arsenic in rice is method dependent are unfounded, and legislation should not be held up based solely on this concern.

Arsenic speciation methods have also been applied to ricecontaining foods and have shown that inorganic arsenic is disproportionately higher in rice bran than in bulk grain [32]. As might be expected, rice-based food products have been shown to have total and inorganic arsenic concentrations that fall within the range of values reported for rice grain. Particular attention has focused on rice-based products for young children because their exposure in terms of $\mu \mathrm{g}$ arsenic $/ \mathrm{kg}$ body weight is higher than for adults. Arsenic speciation methods have shown low concentrations of inorganic arsenic in infant formulas but no increase in arsenic levels as a result of rice starch fortification [43, 73], high levels of total arsenic and inorganic arsenic in toddler formulas using rice syrup as the sugar [42], higher levels of inorganic and total arsenic in infant second foods (jarred solid food meals) where rice is an ingredient [43], and high levels of total and inorganic arsenic in ricebased infant and toddler cereals [34, 41, 74, 75].

\section{Arsenic Speciation in Other Foods}

There have been many studies on arsenic speciation from marine fish (where the major species is invariably arsenobetaine [76-79]) and shellfish (where arsenobetaine 
again predominates but studies occasionally report high levels of inorganic arsenic [80]). Arsenic species are typically very soluble from marine fish and are relatively easily extracted by water and water/methanol extracts [78]. A recent study of 13 different extractants for inorganic arsenic (a minor constituent) of fish tissue showed that dilute acids had the highest extractant efficiency whilst dilute base had the lowest, but most extractants were not significantly different from each other [81]. There is also currently much interest in arsenolipids from marine organisms, and methods using reversed-phase highperformance liquid chromatography (HPLC) coupled to ICP-MS have been developed for their detection and quantification [82-84]. Fish liver and some fish muscle, e.g. tuna, can contain $\mathrm{mg} / \mathrm{kg}$ levels of these arsenolipids, and recent in vitro and in vivo toxicology studies show equivalent toxicity for arsenolipids compared with arsenic(III) [24•, 85]. Marine algae (seaweed) can also contain high (1-100 mg/kg) total arsenic concentration, and here the main arsenic species are arsenosugars. Arsenosugars generally require long chromatographic run-times to fully resolve all arsenic species, and some sugars can be degraded by acid extraction [86].

In 2012, another recent EU proficiency test (IMEP 112), including 74 laboratories, focused on the determination of total and inorganic arsenic in wheat, vegetable (NIST 157a, spinach leaves), and algae; only $20 \%$ of the laboratories reported satisfactory inorganic arsenic results for algae (compared with $85 \%$ for vegetable and $60 \%$ for wheat), suggesting that robust methods are still lacking for samples containing arsenosugars [87•].

As stated above, poultry is another food that has attracted attention as a potential source of arsenic to diet. In the USA, arsenic-based drugs, such as 4-hydroxy-3-nitrophenylarsonic acid or roxarsone, were commonly used as antimicrobials in poultry production until 2013, when arsenic-based drugs were banned by the FDA, with the exception of nitarsone. HPLCICP-MS-based methods have been developed to analyze the parent arsenic drugs and degradation products in poultry litter [88] and soils [89], and in chicken liver [90] and meat [91].

\section{Non-Chromatographic Methods for Inorganic arsenic Determination}

Finally, while most speciation methods use chromatography coupled to ICP-MS or other detectors, a pragmatic approach to quantifying inorganic arsenic, the important form from a regulatory standpoint, has been to use the selective hydride generation of these species. The volatile hydrides can then be passed in a gas stream directly to the detector separated from the other arsenic species and any samples matrix effects. This approach has been used for rice and fish [76]. Hydride generation coupled to ICP-MS was also used for inorganic arsenic in rice after oxidation of the extract and off-line solid-phase extraction by anion exchange [92]. Hydride generation AAS has been used to determine inorganic arsenic in rice samples after initial acid extraction, $\mathrm{H}_{2} \mathrm{O}_{2}$ addition, and solid-phase extraction and concentration of inorganic arsenic [92]. The latter method had similar performance to chromatographyICP-MS methods, with much lower capital costs for instrumentation.

\section{Reference Materials for arsenic Speciation}

The increased interest in arsenic speciation of food, driven in great part by impending WHO guideline limits for inorganic arsenic in rice and FDA guidelines for inorganic arsenic in juice, has outpaced the availability of relevant certified reference materials for arsenic species. This is not the case for mercury, where many certified reference materials have values for total mercury and methylmercury, and illustrates that speciation analysis for arsenic is still not as widely practiced as for mercury. Tort-3, lobster hepatopancreas, produced by the National Research Council of Canada (NRC), has certified values for total arsenic and arsenobetaine. DORM-2, (since superseded by DORM-3 and -4), a dogfish muscle standard produced by the NRC, reported certified values for total arsenic, arsenobetaine, and tetramethylarsonium. NIST released the rice flour Standard Reference Material (SRM) 1568b in 2013 with certified values for DMA, MMA, and inorganic arsenic; this was a recertification of the rice flour 1568a, which had been used by many researchers as a de facto SRM because robust consensus values for DMA and inorganic arsenic could be gained from the scientific literature. NIST also supplies SRM 2669, a human urine certified for arsenic(III), arsenic(V), DMA, MMA, trimethylarsine oxide (TMAO), arsenobetaine, and arsenocholine; while this is not a food $\mathrm{SRM}$, it can at least serve as a reference for retention time and quantification of seven arsenic species. The European proficiency test IMEP 112 we referred to above used NIST $1570 \mathrm{a}$, spinach leaves, as the vegetable sample; therefore, consensus reference inorganic arsenic values for this SRM are available. For arsenosugars and arsenolipids, neither pure reference compounds nor reference materials are readily available.

\section{Spatially Resolved Trace Element Techniques}

Recent developments in spatially-resolved metal analysis techniques, including synchrotron-based X-ray fluorescence (SXRF) microanalysis [62, 93, 94], nano secondary ion mass spectroscopy (nano-SIMS) [95, 96], and laser ablation ICPMS [40] (see Lombi et al., [97] for technique comparison), provide the opportunity to evaluate trace element concentrations in different sections of the food item of investigation. In this section, we focus on arsenic and mercury in rice. SXRF uses focused, high-energy X-rays to cause elements to fluoresce, at an energy and amplitude that correspond to the 
identity and quantity of the element. Samples are moved in the $x, y$, and $z$ direction relative to the beam in 2D mapping, or additionally rotated through $360^{\circ}$ in the case of $3 \mathrm{D}$ imaging. Detection limits vary between individual synchrotron beamlines, but arsenic and mercury concentrations $<1 \mu \mathrm{g} / \mathrm{g}$ have been measured in rice $[62,93,98]$. Elemental mapping studies have shown that chemical species is a strong determinant in whether arsenic is present in the grain (endosperm) or whether it remains trapped in the vasculature that supplies the grain with nutrients from the parent plant (ovular vascular trace [OVT] $[40,95,98]$. DMA is efficiently transported into the endosperm, whereas inorganic arsenite remains trapped in the OVT and bran layers (aleurone) that encase the grain [93] (Fig. 1). Rice grains grown in flooded conditions contained high concentrations of DMA, and nano-SIMS showed that arsenic was localized to the subaleurone tissue region; a particularly protein-rich layer of cells beneath the bran layer. Colocalization with $\mathrm{S}$ suggests strong binding to thiol groups [95]. In the case of mercury, elemental maps of Chinese rice

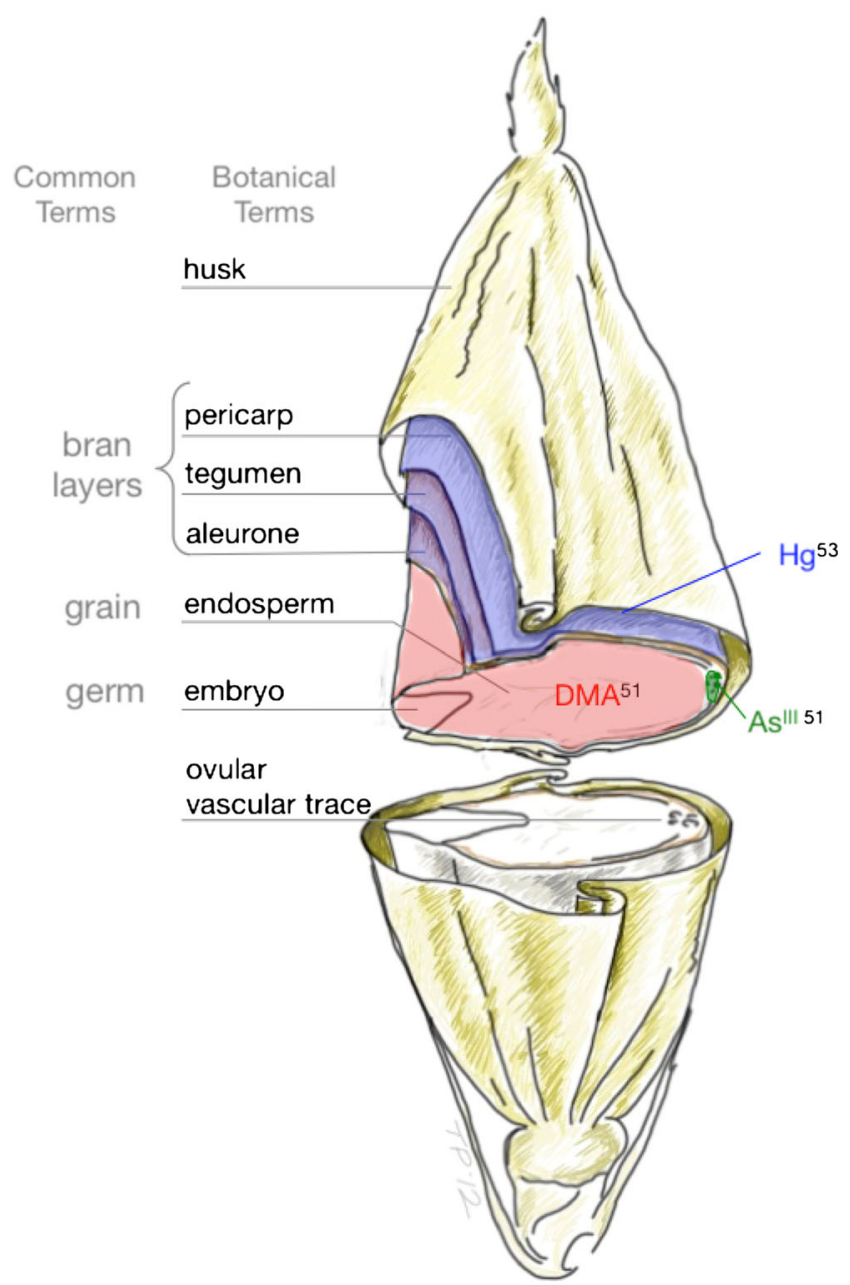

Fig. 1 Spatial location of mercury and arsenic species in rice grain as identified by synchrotron XRF show that mercury is also localized to the outer layers of the grain and OVT. Elemental mapping studies of mercury in rice have appeared relatively recently, and have not used a resolution that allows individual cell layers to be distinguished.

Analysis of arsenic and mercury via synchrotron is hindered by the low abundances typical for these elements in biological tissue in comparison with instrument detection limits. This has led to the use of extended count times of up to 1 minute per pixel in some studies [62], and studies that expose tissue to high concentrations of the target analyte during growth [94]. Spectral overlap is an issue when lead is present in samples for which arsenic is the target analyte, due to the proximity of the lead $\mathrm{L}_{\alpha 1}$ emission line $(10.55 \mathrm{keV})$ to the arsenic $\mathrm{K}_{\alpha}$ line $(10.54 \mathrm{keV})$ (assuming a minimum spectral width of $0.15 \mathrm{keV}$ typical of silicon drift detectors) [99]. Hard X-ray microanalysis of mercury conducted at $15 \mathrm{keV}$, e.g. Meng et al. [100], uses the $\mathrm{L}_{\alpha 1}$ emission line at 9.9, avoiding the $\mathrm{L}_{\beta 1}$ at $11.8 \mathrm{keV}$ that overlaps with arsenic $\mathrm{K}_{\beta}$. The presence of an overlapping emission line can generate false-positive results or inflate count rates, and an additional method of elemental quantification, such as ICPMS should be routinely used to validate the spatially resolved SXRF results, at least in a subsample.

Spatially-resolved speciation information for arsenic and mercury must also be determined via synchrotron-based Xray absorption spectroscopy (XAS) [62, 93], a short-range probe of the coordination chemistry, oxidation state, and interatomic distances of the absorbing atom. The XAS spectrum has two main distinguishable regions, the near edge region (Xray absorption near edge structure [XANES]) and the fine structure region (extended X-ray fine structure spectroscopy [EXAFS]). XANES can provide information about coordination environment and valence, whereas interatomic distance and nearest neighbor identity are determined using the EXAFS region of the spectrum. XANES was used to show that inorganic mercury is retained in the outer husk and bran layer of rice, whereas methylmercury was detected in the endosperm [62]. Although widely used, XAS is not without its technical limitations. This includes the critical influence of the initial choice of standard reference materials, from which the spectra for the unknown sample is derived using linear recombination fitting; the accuracy of XAS is enhanced when information from other techniques informs the standard choice. For arsenic in particular, beam-induced speciation changes can also occur in certain sample types when using XAS. Photoreduction of $\operatorname{arsenic}(\mathrm{V})$ to arsenic(III) has been observed during speciation analysis of arsenic in rice grains [97]. It has also been noted that the typical application of XAS - investigating the speciation of localized elemental features characterized by significantly higher abundances - has a tendency to misrepresent the prevalent speciation of that element in the sample as a whole [93, 97], which leads to recommendations that bulk XAS be used in addition to spatial resolution. 


\section{Conclusions}

Sensitive analytical techniques exist for the detection and speciation of trace elements in foods. Advances in instrumental methods, such as collision and reaction cell ICP-MS, have made this technique more robust to interferences, but challenges still exist due to the complex and variable matrix of foods. In this regard, there is a clear need for more SRMs across a range of food types, analytes, and concentrations to allow for validated method development. Advanced instrumentation such as synchrotron and mass spectrometry nanoprobes are providing greater insight in the speciation and spatial distribution of trace elements in plants, while developments in hyphenated chromatographic-MS techniques continue to increase our knowledge on the extent and transformations of arsenic compounds in plants and animals.

Acknowledgments Both authors acknowledge the support of NIEHS P42 ES007373, NIEHS P01 ES022832, EPA RD83544201. Dr. Punshon is also funded by NIH P20GM104416.

\section{Compliance with Ethics Guidelines}

Conflict of Interest Brian Jackson and Tracy Punshon declare that they have no conflict of interest.

Human and Animal Rights and Informed Consent This article does not contain any studies with human or animal subjects performed by any of the authors.

\section{References}

Papers of particular interest, published recently, have been highlighted as:

- Of importance

•- Of major importance

1. US Department of Health and Human Services. US Food and Drug Administration. CPG Sec. 540.600 Fish, shellfish, crustaceans and other aquatic animals - fresh, frozen or processed methyl mercury. Bethesda (MA): US FDA; 2014.

2. European Commission. 2013. Amending regulation (ec) no 1881/ 2006 as regards maximum lelvels of cadmium in foodstuffs. http:// eur-lex.europa.eu/legal-content/EN/TXT/HTML/?uri= CELEX:32014R0488\&from=EN.

3. Murphy CJ, MacNeil JD, Capar SG. Best practices for singlelaboratory validation of chemical methods for trace elements in foods. Part i-background and general considerations. J Aoac Int. 2013;96:190-203.

4. Julshamn K, Maage A, Norli HS, Grobecker KH, Jorhem L, Fecher P, et al. Determination of arsenic, cadmium, mercury, and lead in foods by pressure digestion and inductively coupled plasma/mass spectrometry: first action 2013.06. J Aoac Int. 2013;96:1101-2.

5. Wangkarn S, Pergantis SA. Determination of arsenic in organic solvents and wines using microscale flow injection inductively coupled plasma mass spectrometry. J Anal At Spectrom. 1999;14:657-62.

6. Entwisle J, Hearn R. Development of an accurate procedure for the determination of arsenic in fish tissues of marine origin by inductively coupled plasma mass spectrometry. Spectrochim Acta Part B-At Spectrosc. 2006;61:438-43.

7. Allain P, Jaunault L, Mauras Y, Mermet JM, Delaporte T. Signal enhancement of elements due to the presence of carboncontaining compounds in inductively coupled plasma mass spectrometry. Anal Chem. 1991;63:1497-8.

8. Grindlay G, Mora J, de Loos-Vollebregt M, Vanhaecke F. A systematic study on the influence of carbon on the behavior of hardto-ionize elements in inductively coupled plasma-mass spectrometry. Spectrochim Acta Part B-Atomic Spectrosc. 2013;86:42-9.

9. Commission CA. 2014. Report of the eighth session of the codex committee on contaminants in foods. CL2014/11-CF. Geneva.

10. Baer I, Baxter M, Devesa V, Velez D, Raber G, Rubio R, et al. Performance of laboratories in speciation analysis in seafood case of methylmercury and inorganic arsenic. Food Control. 2011;22:1928-34.

11. Francesconi KA, Kuehnelt D. Determination of arsenic species: acritical review of methods and applications, 2000-2003. Analyst. 2004;129:373-95.

12. McCurdy E, Woods G. The application of collision/reaction cell inductively coupled plasma mass spectrometry to multi-element analysis in variable sample matrices, using $\mathrm{He}$ as a non-reactive cell gas. J Anal At Spectrom. 2004;19:607-15.

13. D'llio S, Violante N, Majorani C, Petrucci F. Dynamic reaction cell ICP-MS for determination of total As, $\mathrm{Cr}$, Se, and $\mathrm{V}$ in complex matrices: still a challenge? A review. Anal Chim Acta. 2011;698:6-13.

14. Sucharova J. Optimisation of DRC-ICP-MS for determining selenium in plants. J Anal At Spectrom. 2011;26:1756-62.

15. Wei YH, Zhang JY, Zhang DW, Luo LG, Tu TH. Simultaneous determination of Se, trace elements and major elements in Se-rich rice by dynamic reaction cell inductively coupled plasma mass spectrometry (DRC-ICP-MS) after microwave digestion. Food Chem. 2014;159:507-11.

16. Guo W, Hu S, Li X, Zhao J, Jin S, Liu W, et al. Use of ionmolecule reactions and methanol addition to improve arsenic determination in high chlorine food samples by DRC-ICP-MS. Talanta. 2011;84:887-94.

17. Jackson BP, Liba A, Nelson J. 2015. Advantages of reaction cell ICP-MS on doubly charged interferences for arsenic and selenium analysis in foods. J Anal At Spectrom. doi:10.1039/C4JA00310A.

18. Larsen EH, Sturup S. Carbon-enhanced inductively-coupled plasma-mass spectrometric detection of arsenic and selenium and its application to arsenic speciation. J Anal At Spectrom. 1994;9:1099-105.

19. Khan N, Jeong IS, Hwang IM, Kim JS, Choi SH, Nho EY, et al. Method validation for simultaneous determination of chromium, molybdenum and selenium in infant formulas by ICP-OES and ICP-MS. Food Chem. 2013;141:3566-70.

20. Pacquette LH, Szabo A, Thompson JJ. Application of inductively coupled plasma/mass spectrometry for the measurement of chromium, selenium, and molybdenum in infant formula and adult nutritional products: first action 2011.19. J AOAC Int. 2012;95: 588-98.

21. Sullivan D, Zywicki R, Yancey M. Method for the determination of total selenium in a wide variety of foods using inductively coupled plasma/mass spectrometry. J AOAC Int. 2013;96:786-94.

22. Nixon DE, Neubauer KR, Eckdahl SJ, Butz JA, Burritt MF. Comparison of tunable bandpass reaction cell inductively coupled plasma mass spectrometry with conventional inductively coupled plasma mass spectrometry for the determination of heavy metals in whole blood and urine. Spectrochim Acta Part B-At Spectrosc. 2004;59:1377-87. 
23. Schoof RA, Yost LJ, Eickhoff J, Crecelius EA, Cragin DW, Meacher DM, et al. A market basket survey of inorganic arsenic in food. Food Chem Toxicol. 1999;37:839-46.

24. Meyer S, Matissek M, Mueller SM, Taleshi MS, Ebert F, Francesconi KA, et al. In vitro toxicological characterisation of three arsenic-containing hydrocarbons. Metallomics. 2014;6: 1023-33. First report of potential toxicity of this under-studied class of arsenic compounds in food.

25. Jackson BP, Bertsch PM. Determination of arsenic speciation in poultry wastes by IC-ICP-MS. Environ Sci Technol. 2001;35: 4868-73.

26. Garbarino JR, Bednar AJ, Rutherford DW, Beyer RS, Wershaw RL. Environmental fate of roxarsone in poultry litter. I. Degradation of roxarsone during composting. Environ Sci Technol. 2003;37:1509-14.

27. Wershaw RL, Rutherford DW, Rostad CE, Garbarino JR, Ferrer I, Kennedy KR, et al. Mass spectrometric identification of an azobenzene derivative produced by smectite-catalyzed conversion of 3-amino-4-hydroxyphenylarsonic acid. Talanta. 2003;59:1219 26.

28. Stolz JF, Perera E, Kilonzo B, Kail B, Crable B, Fisher E, et al. Biotransformation of 3-nitro-4-hydroxybenzene arsonic acid (roxarsone) and release of inorganic arsenic by clostridium species. Environ Sci Technol. 2007;41:818-23.

29. Kawalek J. 2011. Arsenic speciation in broiler chickens. 275.30.US Food And Drug Administration.

30. Gilbert-Diamond D, Cottingham KL, Gruber JF, Punshon T, Sayarath V, Gandolfi AJ, et al. Rice consumption contributes to arsenic exposure in us women. Proc Natl Acad Sci U S A. 2011;108:20656-60

31. Meharg AA, Williams PN, Adomako E, Lawgali YY, Deacon C, Villada A, et al. Geographical variation in total and inorganic arsenic content of polished (white) rice. Environ Sci Technol. 2009;43:1612-7.

32. Sun G-X, Williams PN, Carey A-M, Zhu Y-G, Deacon C, Raab A, et al. Inorganic arsenic in rice bran and its products are an order of magnitude higher than in bulk grain. Environ Sci Technol. 2008;42:7542-6.

33. Stone R. Food safety - arsenic and paddy rice: a neglected cancer risk? Science. 2008;321:184-5.

34. Meharg AA, Sun GX, Williams PN, Adomako E, Deacon C, Zhu $\mathrm{YG}$, et al. Inorganic arsenic levels in baby rice are of concern. Environ Pollut. 2008;152:746-9.

35. Meharg AA, Deacon C, Campbell RCJ, Carey A-M, Williams PN, Feldmann J, et al. Inorganic arsenic levels in rice milk exceed EU and US drinking water standards. J Environ Monit. 2008;10:42831.

36. Williams PN, Price AH, Raab A, Hossain SA, Feldmann J, Meharg AA. Variation in arsenic speciation and concentration in paddy rice related to dietary exposure. Environ Sci Technol. 2005;39:5531-40.

37. D'Ilio S, Alessandrelli M, Cresti R, Forte G, Caroli S. Arsenic content of various types of rice as determined by plasma-based techniques. Microchem J. 2002;73:195-201.

38. Heitkemper DT, Vela NP, Stewart KR, Westphal CS. Determination of total and speciated arsenic in rice by ion chromatography and inductively coupled plasma mass spectrometry. J Anal At Spectrom. 2001;16:299-306.

39.• Norton GJ, Pinson SRM, Alexander J, McKay S, Hansen H, Duan G-L, et al. Variation in grain arsenic assessed in a diverse panel of rice (oryza sativa) grown in multiple sites. New Phytol. 2012;193: 650-64. Showed that genetic variability was a main driver of grain arsenic concentration and suggested that breeding strategies could be used to reduce arsenic in rice grains.

40. Carey AM, Lombi E, Donner E, de Jonge MD, Punshon T, Jackson BP, et al. A review of recent developments in the speciation and location of arsenic and selenium in rice grain. Anal Bioanal Chem. 2012;402:3275-86.

41. Carbonell-Barrachina AA, Wu X, Ramirez-Gandolfo A, Norton GJ, Burlo F, Deacon C, et al. Inorganic arsenic contents in ricebased infant foods from Spain, UK, China and USA. Environ Pollut. 2012;163:77-83

42. Jackson BP, Taylor VF, Karagas MR, Punshon T, Cottingham KL. Arsenic, organic foods, and brown rice syrup. Environ Health Perspect. 2012;120:623-6.

43. Jackson BP, Taylor VF, Punshon T, Cottingham KL. Arsenic concentration and speciation in infant formulas and first foods. Pure Appl Chem. 2012;84:215-23.

44. Llorente-Mirandes T, Calderon J, Lopez-Sanchez JF, Centrich F, Rubio R. A fully validated method for the determination of arsenic species in rice and infant cereal products. Pure Appl Chem. 2012;84:225-38.

45. Munera-Picazo S, Ramirez-Gandolfo A, Burlo F, Antonio Carbonell-Barrachina A. Inorganic and total arsenic contents in rice-based foods for children with celiac disease. J Food Sci. 2014;79:T122-8.

46. Feldmann J, Krupp EM. Critical review or scientific opinion paper: arsenosugars-a class of benign arsenic species or justification for developing partly speciated arsenic fractionation in foodstuffs? Anal Bioanal Chem. 2011;399:1735-41.

47. Castlehouse H, Smith C, Raab A, Deacon C, Meharg AA, Feldmann J. Biotransformation and accumulation of arsenic in soil amended with seaweed. Environ Sci Technol. 2003;37:951-7.

48. Rose M, Lewis J, Langford N, Baxter M, Origgi S, Barber M, et al. Arsenic in seaweed-forms, concentration and dietary exposure. Food Chem Toxicol. 2007;45:1263-7.

49. Hu P, Huang J, Ouyang Y, Wu L, Song J, Wang S, et al. Water management affects arsenic and cadmium accumulation in different rice cultivars. Environ Geochem Health. 2013;35:767-78.

50. Moreno-Jimenez E, Meharg AA, Smolders E, Manzano R, Becerra D, Sanchez-Llerena J, et al. Sprinkler irrigation of rice fields reduces grain arsenic but enhances cadmium. Sci Total Environ. 2014;485-486:468-73.

51. Meharg AA, Norton G, Deacon C, Williams P, Adomako EE, Price A, et al. Variation in rice cadmium related to human exposure. Environ Sci Technol. 2013;47:5613-8.

52. Tsukahara T, Ezaki T, Moriguchi J, Furuki K, Shimbo S, MatsudaInoguchi N, et al. Rice as the most influential source of cadmium intake among general japanese population. Sci Total Environ. 2003;305:41-51.

53. da Silva DG, Junior MMS, Silva LOB, Portugal LA, Matos GD, Ferreira SLC. Determination of cadmium in rice by electrothermal atomic absorption spectrometry using aluminum as permanent modifier. Anal Methods. 2011;3:2495-500.

54. Akamatsu S, Yoshioka N, Mitsuhashi T. Sensitive determination of cadmium in brown rice and spinach by flame atomic absorption spectrometry with solid-phase extraction. Food Addit Contam Part a-Chem Anal Control Expo Risk Assess. 2012;29:1696-700.

55. Zhang H, Feng XB, Larssen T, Shang L, Li P. Bioaccumulation of methylmercury versus inorganic mercury in rice (oryza sativa 1.) grain. Environ Sci Technol. 2010;44:4499-504.

56. Sovik ML, Larssen T, Vogt RD, Wibetoe G, Feng XB. Potentially harmful elements in rice paddy fields in mercury hot spots in guizhou, china. Appl Geochem. 2011;26:167-73.

57. Li L, Wang FY, Meng B, Lemes M, Feng XB, Jiang GB. Speciation of methylmercury in rice grown from a mercury mining area. Environ Pollut. 2010;158:3103-7.

58. Qiu GL, Feng XB, Li P, Wang SF, Li GH, Shang LH, et al. Methylmercury accumulation in rice (oryza sativa 1.) grown at abandoned mercury mines in guizhou, china. J Agric Food Chem. 2008;56:2465-8. 
59. Wang X, Ye ZH, Li B, Huang LN, Meng M, Shi JB, et al. Growing rice aerobically markedly decreases mercury accumulation by reducing both hg bioavailability and the production of MeHG. Environ Sci Technol. 2014;48:1878-85.

60. Rothenberg SE, Feng XB, Dong B, Shang LH, Yin RS, Yuan XB. Characterization of mercury species in brown and white rice (oryza sativa 1.) grown in water-saving paddies. Environ Pollut. 2011;159:1283-9.

61. Meng M, Li B, Shao JJ, Wang T, He B, Shi JB, et al. Accumulation of total mercury and methylmercury in rice plants collected from different mining areas in china. Environ Pollut. 2014;184:179-86.

62. Meng B, Feng XB, Qiu GL, Anderson CWN, Wang JX, Zhao L. Localization and speciation of mercury in brown rice with implications for pan-asian public health. Environ Sci Technol. 2014;48: 7974-81.

63. Drennan-Harris LR, Wongwilawan S, Tyson JF. Trace determination of total mercury in rice by conventional inductively coupled plasma mass spectrometry. J Anal At Spectrom. 2013;28:259-65.

64. Zhao FJ, Zhu YG, Meharg AA. Methylated arsenic species in rice: geographical variation, origin, and uptake mechanisms. Environ Sci Technol. 2013;47:3957-66.

65. Lomax C, Liu WJ, Wu LY, Xue K, Xiong JB, Zhou JZ, et al. Methylated arsenic species in plants originate from soil microorganisms. New Phytol. 2012;193:665-72.

66. Sanchez-Rodas D, Corns WT, Chen B, Stockwell PB. Atomic fluorescence spectrometry: a suitable detection technique in speciation studies for arsenic, selenium, antimony and mercury. J Anal At Spectrom. 2010;25:933-46.

67. Foster S, Maher W, Krikowa F, Apte S. A microwave-assisted sequential extraction of water and dilute acid soluble arsenic species from marine plant and animal tissues. Talanta. 2007;71:53749.

68. Maher W, Foster S, Krikowa F, Donner E, Lombi E. Measurement of inorganic arsenic species in rice after nitric acid extraction by HPLC-ICPMS: verification using xanes. Environ Sci Technol. 2013;47:5821-7.

69. Nishimura T, Hamano-Nagaoka M, Sakakibara N, Abe T, Maekawa Y, Maitani T. Determination method for total arsenic and partial-digestion method with nitric acid for inorganic arsenic speciation in several varieties of rice. Food Hyg Saf Sci. 2010;51: $178-81$.

70. Huang JH, Ilgen G, Fecher P. Quantitative chemical extraction for arsenic speciation in rice grains. J Anal At Spectrom. 2010;25: $800-2$.

71. Nookabkaew S, Rangkadilok N, Mahidol C, Promsuk G, Satayavivad J. Determination of arsenic species in rice from thailand and other asian countries using simple extraction and HPLCICP-MS analysis. J Agric Food Chem. 2013;61:6991-8.

72. de la Calle MB, Emteborg H, Linsinger TPJ, Montoro R, Sloth JJ, Rubio R, et al. Does the determination of inorganic arsenic in rice depend on the method? Trac Trends Anal Chem. 2011;30:641-51.

73. Vela NP, Heitkemper DT. Total arsenic determination and speciation in infant food products by ion chromatography-inductively coupled plasma-mass spectrometry. J Aoac Int. 2004;87:244-52.

74. Juskelis R, Li W, Nelson J, Cappozzo JC. Arsenic speciation in rice cereals for infants. J Agric Food Chem. 2013;61:10670-6.

75. Rintala E-M, Ekholm P, Koivisto P, Peltonen K, Venalainen E-R. The intake of inorganic arsenic from long grain rice and rice-based baby food in finland - low safety margin warrants follow up. Food Chem. 2014;150:199-205.

76. Musil S, Petursdottir AH, Raab A, Gunnlaugsdottir H, Knipp E, Feldmann J. Speciation without chromatography using selective hydride generation: inorganic arsenic in rice and samples of marine origin. Anal Chem. 2014;86:993-9.
77. Kirby J, Maher W. Measurement of water-soluble arsenic species in freeze-dried marine animal tissues by microwave-assisted extraction and HPLC-ICP-MS. J Anal At Spectrom. 2002;17:838-43.

78. McKiernan JW, Creed JT, Brockhoff CA, Caruso JA, Lorenzana RM. A comparison of automated and traditional methods for the extraction of arsenicals from fish. J Anal At Spectrom. 1999;14: 607-13.

79. Ackley KL, B'Hymer C, Sutton KL, Caruso JA. Speciation of arsenic in fish tissue using microwave-assisted extraction followed by HPLC-ICP-MS. J Anal At Spectrom. 1999;14:845-50.

80. Sloth JJ, Julshamn K. Survey of total and inorganic arsenic content in blue mussels (mytilus edulis l.) from norwegian fiords: revelation of unusual high levels of inorganic arsenic. J Agric Food Chem. 2008;56:1269-73.

81. Petursdottir AH, Gunnlaugsdottir H, Krupp EM, Feldmann J. Inorganic arsenic in seafood: does the extraction method matter? Food Chem. 2014;150:353-9.

82. Amayo KO, Raab A, Krupp EM, Feldmann J. Identification of arsenolipids and their degradation products in cod-liver oil. Talanta. 2014;118:217-23.

83. Amayo KO, Raab A, Krupp EM, Gunnlaugsdottir H, Feldmann J. Novel identification of arsenolipids using chemical derivatizations in conjunction with RP-HPLC-ICPMS/ESMS. Anal Chem. 2013;85:9321-7.

84. Sele V, Sloth JJ, Lundebye A-K, Larsen EH, Berntssen MHG, Amlund $\mathrm{H}$. Arsenolipids in marine oils and fats: a review of occurrence, chemistry and future research needs. Food Chem. 2012;133:618-30.

85. Meyer S, Schulz J, Jeibmann A, Taleshi MS, Ebert F, Francesconi KA, Schwerdtle T. 2014. Arsenic-Meyer S, Schulz J, Jeibmann A, Taleshi MS, Ebert F, Francesconi KA, Schwerdtle T. 2014. Arsenic-containing hydrocarbons are toxic in the in vivo model drosophila melanogaster. Metallomics 6:2010-2014.

86. Gamble BM, Gallagher PA, Shoemaker JA, Wei X, Schwegel CA, Creed JT. An investigation of the chemical stability of arsenosugars in simulated gastric juice and acidic environments using IC-ICP-MS and IC-ESI-MS/MS. Analyst. 2002;127:781-5.

87. de la Calle MB, Baer I, Robouch P, Cordeiro F, Emteborg H, Baxter MJ, et al. Is it possible to agree on a value for inorganic arsenic in food? The outcome of IMEP-112. Anal Bioanal Chem. 2012;404:2475-88. Interesting study on the analytical variability in arsenic speciation determination for three identical food types across 74 different laboratories worldwide.

88. Jackson BP, Bertsch PM, Cabrera ML, Camberato JJ, Seaman JC, Wood CW. Trace element speciation in poultry litter. J Environ Qual. 2003;32:535-40.

89. Jackson BP, Seaman JC, Bertsch PM. Fate of arsenic compounds in poultry litter upon land application. Chemosphere. 2006;65: 2028-34.

90. Conklin SD, Shockey N, Kubachka K, Howard KD, Carson MC. Development of an ion chromatography-inductively coupled plasma-mass spectrometry method to determine inorganic arsenic in liver from chickens treated with roxarsone. J Agric Food Chem. 2012;60:9394-404.

91. Nachman KE, Baron PA, Raber G, Francesconi KA, Navas-Acien A, Love DC. Roxarsone, inorganic arsenic, and other arsenic species in chicken: a US-based market basket sample. Environ Health Perspect. 2013;121:818-24.

92. Rasmussen RR, Qian YT, Sloth JJ. SPE HG-AAS method for the determination of inorganic arsenic in rice-results from method validation studies and a survey on rice products. Anal Bioanal Chem. 2013;405:7851-7.

93. Lombi E, Scheckel KG, Pallon J, Carey AM, Zhu YG, Meharg AA. Speciation and distribution of arsenic and localization of nutrients in rice grains. New Phytol. 2009;184:193-201. 
94. Carey AM, Norton GJ, Deacon C, Scheckel KG, Lombi E, Punshon T, et al. Phloem transport of arsenic species from flag leaf to grain during grain filling. New Phytol. 2011;192:87-98.

95. Moore KL, Schroder M, Lombi E, Zhao F-J, McGrath SP, Hawkesford MJ, et al. NanoSIMS analysis of arsenic and selenium in cereal grain. New Phytol. 2010;185:434-45.

96. Dickinson M, Heard PJ, Barker JHA, Lewis AC, Mallard D, Allen GC. Dynamic SIMS analysis of cryo-prepared biological and geological specimens. Appl Surf Sci. 2006;252:6793-6.

97. Lombi E, Scheckel KG, Kempson I. In situ analysis of metal(loid)s in plants: state of the art and artefacts. Environ Exp Bot. 2011;72:3-17.
98. Meharg A, Lombi E, Williams PN, Scheckel KG, Feldmann J, Raab A, et al. Speciation and localization of arsenic in white and brown rice grains. Environ Sci Technol. 2008;42:1051-7.

99. Punshon T, Ricachenevsky FK, Hindt MF, Socha A, Zuber H. Methodological approaches for using synchrotron x-ray fluorescence (sxrf) imaging as a tool in ionomic characterization: examples from whole plant imaging of arabdiopsis thaliana. Metallomics. 2013;5:1133-45.

100. Meng B, Feng X, Qiu G, Cai Y, Wang D, Li P, et al. Distribution patterns of inorganic mercury and methylmercury in tissues of rice (oryza sativa 1.) plants and possible bioaccumulation pathways. J Agric Food Chem. 2010;58:4951-8. 